\title{
Teachers' Awareness and Participation in the School-Based Teacher Development Programme in Mathugama Education Zone
}

\author{
Sandamali Tennakoon ${ }^{1}$, F. M. Nawastheen $*^{2}$ \\ ${ }^{I}$ Bilingual Education Branch, Ministry of Education, Isurupaya, Battaramulla, Sri Lanka \\ ${ }^{2 *}$ Department of Secondary \& Tertiary Education, Faculty of Education, The Open University of Sri Lanka.
}

\begin{abstract}
Teacher professional development is directly related to student educational achievements. School-based teacher development programmes in Sri Lanka have been implemented at the school level recently. The study aimed to find out the status of awareness about SBTD and the participation of teachers in the SBTD programme. In addition, it also aimed to identify the nature of activities done in schools under the SBTD programme. The study employed a survey research design and the collected data from a sample of $\mathbf{4 8}$ teachers selected randomly from Mathugama Education Zone in Sri Lanka. Frequency and percentage used for analysis for data. Data analysis showed that teachers in the zone were aware of the school-based development and its various activities implemented at their schools. However, there was a lack of teacher participation in some activities where teachers might get hands-on experiences related to their profession. Therefore, the researchers recommended that school principals ensure teachers' involvement in the SBTD activities by finding out the reasons behind the lack of participation.
\end{abstract}

Keywords: Professional Development, School-Based Teacher Development; Teacher awareness; Teacher participation

\section{INTRODUCTION}

$\mathrm{T}$ he current socio-economic system we live in today is highly complex than ever before. In such context, 'Education" has become a phenomenon of optimum public interest. The avenues for education and higher education are increasing rapidly, making the concept very complex to understand. At the same time, the rapid changes in science and technology significantly impact education, especially on teaching professionals. Therefore, the teachers should constantly train, assuring that they possess adequate professional competencies, which is the crucial mechanism of classroom teaching and learning and overall student achievement leading to the student's holistic development. Due to these rapid worldly changes, different educational transactions took place in the education system, challenging the teacher's role in different aspects. In this sense, the need to revisit the aims and objectives of the teaching-learning process and procedures of teacher development was apparent. The belief in delivering quality education through quality teachers led to new dimensions to improve teacher development programmes. Fullen (1995) defines professional development as continuous learning, which is consisted of formal and informal learning of a teacher. Therefore, keep-upto-date professional skills or continued professional development to minimize the gap between the theory and practice was a primary concern in proposals for teacher education. Teacher Development is the 'key' to developing the students' quality of the outcomes (Bandara 2018A). In such a situation, teachers' updated knowledge and skill significantly affect students' development process. Therefore, teachers have to update and intensify their knowledge, skills, attitudes and practices according to students' current expansive demand. In Sri Lanka, various efforts have been made to enhance teachers' careers (Nawastheen et al., 2017). In Sri Lanka, graduates from various disciplines are recruited directly into the teaching service without having pre-teacher training. However, the government is conducting several pre-and inservice teacher training programmes for the professional development of such teachers. One such activity is the development of teachers' professional skills at the school level.

\section{School-Based Teacher Development (SBTD)}

School-Based Teacher Development is an essential concept because it allows teachers to plan, organize, and implement their development programs, considering their needs and those of students and the school. SBTD programmes are identified as a mechanism that operates in the schools by schools for teacher professional development. Linda (2005) states that many schools have improved teaching practices and student achievement while building professional knowledge. Strengthening the teachers is the quickest way to change the effectiveness of a school for the better. School leaders and teachers are instrumental in facilitating professional learning communities focused on student learning. Therefore, to facilitate successful classroom practices in any activity like project and problem solving, workshops, seminars, exhibitions, and such strategies are organized and practised by any teacher or a group of teachers. Developing teachers' professional skills in a particular school within the locality or the context is imperative since it addresses specific problems or necessities unique to that school. That school-oriented intervention is targeting teacher development considered as SBTD. In other words, if a strategic plan is prepared centrally for the professional development of all teachers of the country, that will hardly address the actual needs of the teachers representing varying contexts since we cannot 
assume all teachers at all schools have the exact professional needs. Therefore, the same developmental programmes may not equally fit all teachers.

In addition, Bandara (2018A) divided the Professional development programs for teachers into two groups: school-Based Teacher Development (SBTD) and Non-School-Based Teacher Development (NSBTD). As principals and teachers at the schools create, organize, implement, own, and oversee the SBTD, it is considered a successful technique for teacher professional development. The NSBTD program, which is organized and implemented by external organizations or institutes of the schools. There is no argument that these two professional development programs help develop teachers' knowledge, skills, competencies, and attitudes.

\section{School-Based Teacher Development Programmes in Sri Lanka}

Recognizing the importance of a competency-based approach to teacher education in ensuring effective and productive education transactions, Sri Lanka's Ministry of Education implemented innovative activities in their SchoolBased Management Program (SBM). SBM refers to a decentralized organizational structure in which decisionmaking authority previously held by the centre or local education authorities is delegated to a body at the school level comprised of representatives from parents, teachers, community members, the local authority, and the school principal. It was agreed to experiment with a modified version of the SBM as part of the World Bank-funded Education Sector Development Framework and Program (ESDFP) from 2006 to 2011. The SBM was called "Programme for School Improvement (PSI), in which one of the aims is to introduce teacher development programmes at the school level. Later, PSI was introduced under Education Sector Development Framework and Programme (ESDFP) for 2012 to 2016 to address the challenges and issues of the school education system. It incorporates the strategies and programmes planned to promote the equity, quality, and efficiency of the general education system under the following policy themes: Theme 1- Increasing access and participation in primary and secondary education; Theme 2- Improving quality of primary and secondary education and Theme 3 -Strengthening governance and service delivery of education services. SBTD programme was integrated with PSI and aimed to strengthen teacher development through various school-level activities further. Then, under the General Education Modernization Project (GEMP) Enhanced Programme for School improvements (EPSI) in place of PSI was introduced in 2016 with the support of the world bank. The EPSI is expected to significantly expand and improve the performance of the general education sector. The EPSI will help schools conduct regular school-based management of planning, implementation, school self-review, reporting of results, and further fine-tuning and updating the school plans. Schoollevel activities, including the School-Based Professional
Teacher Development (SBPTD) programme, were supported through the EPSI.

The SBTD programme operated under theme two of Education Sector Development Framework and programme (ESDFP) to improve the quality of primary and secondary education in the country where 'teacher development' is emphasized as a significant policy initiative within the overall policy framework of education quality development. SBTD, the particular endeavour directed by the Ministry of Education, which aimed at promoting school-based management and development, has now met with the end of its five-year introductory period. During the last five-year period, allocations were granted to the schools to conduct school-oriented programmes for the development of teachers according to the guidelines provided zonal level. Moreover, from 2017, the schools are expected to operate independently, giving special attention to professional development requirements. In any innovative initiatives, teachers 'awareness and active participation are essential. If the teachers are ignorant of the innovative programmes and do not participate, the programmes' objectives will fail. Therefore, this study aimed to find out the level of awareness about SBTD and the participation of teachers in the SBTD programme. In addition, it also aimed to identify the nature of activities done in schools under the SBTD programme.

\section{Statement of the Problem}

Even if an educational system has good policies, educational goals, administrative practices, and schools, including all necessary resources and facilities, the system's success is still dependent on teachers (Nawastheen et al., 2017). SBTD was one of the innovative programmes that the MOE implemented until 2015. School-based Teacher professional development (SBTPD) is now in place instead of SBTD. Therefore, it is essential to evaluate teachers' awareness and involvement with the implemented SBTD programmes in this context. The findings would facilitate to implementation of the SBTPD successfully. Therefore, the present study aimed to find out the status of awareness about SBTD and the participation of teachers in the SBTD programme. Researchers developed the following study questions to achieve the aim of the study: What was the status of teachers' awareness about the SBTD? Moreover, what was the teachers' participation in the SBTD programmes?

\section{LITERATURE REVIEW}

Yoon et al. (2007) pointed out that Teacher Professional development is a vital tool for improving classroom teaching and student achievement. They illustrated a model which consisted of three steps on how the development of teachers' influences student achievement:

1. First, professional development enhances teacher knowledge and skills.

2. Second, better knowledge and skills improve classroom teaching and

3. Third, improved teaching raises student achievement. 
If one link is weak or missing, better student learning cannot be expected. For example, if a teacher fails to apply new ideas from professional development to classroom instruction, students will not benefit from the teacher's professional development (Yoon et al., 2007:4). Therefore, if a malfunction happens in any of the three steps in the above model, it is evident that the optimum level of student performance cannot be guaranteed. Similarly, the situated learning approach supports this point as it identifies learning as a socio-cultural phenomenon rather than the action of an individual acquiring knowledge from a decontextualized body of knowledge. Therefore, it is clear that the School-Based Teacher Development concept is considered an effective tool for improving the teaching-learning and evaluation process and, thereby, students' total development.

Very few studies have been conducted in this field. Bandara (2018A) investigated how Sri Lankan secondary schools implemented the SBTD programs. The study of Bandara (2018A) employed a case study with a sample of school principals. He found that the Majority of ten school Principals were not aware of the concepts of SBTD programs, and they required more awareness about SBTD programs. Bandara (2018 B), in another study, examined how organizational factors influenced SBTD programs. He concluded that endemic systemic problems in and across the Sri Lankan Education system had left schools without national or local policy and professional development frameworks regarding the provision of SBTD in Sri Lankan secondary schools (Bandara 2018 B: P1133).

Kugamoorthy (2017), in her study on School-Based Teacher Development: Opportunities and Challenges for Teachers in Jaffna District, found that majority of the teachers mentioned that the way activities conducted under the schoolbased teacher development satisfied their professional development needs to some extent and moderately. However, it is noted that a considerable number of teachers expressed that the activities satisfied their needs to the slightest extent. More than 20\% indicated that experts were not invited to help update their knowledge, and arrangements were not made for sharing the experiences and documents. Therefore, the results revealed that the school-based teacher development activities did not fully satisfy their professional development needs. Arachchi (2015), in his study about the SBTD programmes, stated that schools did not have the appropriate mechanism to identify teachers' professional needs to carry out the SBTD programmes. he further postulated that teachers were not ready to change their traditional teaching practices. The study of Silva et al. (2007) found that the schools could not identify the professional development needs of teachers to improve students learning achievements through a school-based system (Silva et al., 2007:16).

\section{METHODOLOGY}

The present research was conducted using the survey research design. Data was collected using a questionnaire from the 48 secondary school teachers randomly selected from the Mathugama education zone. The questionnaire was prepared, including three main trust areas, namely, Aspiration for professional development- to find out the level of teachers' awareness regarding SBTD and the degree of participation of the teachers in the SBTD programmes. The data obtained by questionnaire were tabulated and analyzed by using frequencies and percentages. The questionnaires were administrated to the selected teachers via divisional directors in the Mathugama education.

\section{FINDINGS AND DISCUSSION}

Items with five Likert scale scales 1 (Totally disagree) to 5 (Totally agree) was used to assess the respondents' status of awareness about the SBTD programmes.

Table 1: Teachers' awareness about the SBTD

\begin{tabular}{|c|c|c|c|c|c|}
\hline Item & 1 & 2 & 3 & 4 & 5 \\
\hline $\begin{array}{c}\text { I am aware of what the SBTD } \\
\text { programme was. }\end{array}$ & 2.31 & 6.02 & 4.17 & 23.51 & 63.99 \\
\hline $\begin{array}{c}\text { I am aware of the various activities } \\
\text { their SBTD implemented at the } \\
\text { school level. }\end{array}$ & 6.17 & 7.96 & 2.61 & 20.32 & 62.94 \\
\hline $\begin{array}{c}\text { I knew that the activities of SBTD } \\
\text { aimed to give various experiences to } \\
\text { develop skills related to my teaching } \\
\text { profession. }\end{array}$ & 6.25 & 6.25 & 25.0 & 41.67 & 20.83 \\
\hline
\end{tabular}

Table 1 shows teachers' awareness about the SBTD programmes, and its activities implemented at the school level. Most of the teachers (87.5\%) are aware of the SBTD and its various programmes $(83.26 \%)$ and about the programme's aims (62.5\%). However, the teachers' awareness is contradicted with the findings of Bandara (2018). He claimed that there was a lack of awareness about the SBTD programmes among teachers. As the study sample was from Western Province, teachers might be more aware of SBTD programmes than other areas. In addition, Since the teachers claimed that they knew about the experiences in various SBTD activities, it is important to investigate the nature of their activities at the schools. Table 2 shows that teachers' experience of participation in different SBTD activities at their school level.

Table 2: Essential' experiences of participation in different SBTD activities.

\begin{tabular}{|c|c|c|c|c|}
\hline $\begin{array}{c}\text { Types of } \\
\text { activities }\end{array}$ & $\begin{array}{c}\text { Very } \\
\text { frequently } \\
\text { participated }\end{array}$ & $\begin{array}{c}\text { Frequently } \\
\text { participated }\end{array}$ & $\begin{array}{c}\text { Rarely } \\
\text { participated }\end{array}$ & $\begin{array}{c}\text { Not } \\
\text { participated }\end{array}$ \\
\hline Seminars & 22.92 & 60.42 & 4.17 & 12.5 \\
\hline Workshops & 16.67 & 64.58 & 2.08 & 16.67 \\
\hline $\begin{array}{c}\text { Hands-on } \\
\text { training }\end{array}$ & 14.58 & 54.17 & 12.50 & 18.75 \\
\hline $\begin{array}{c}\text { Guest } \\
\text { lectures }\end{array}$ & 12.50 & 39.58 & 10.42 & 37.50 \\
\hline $\begin{array}{c}\text { Get-together } \\
\text { Group/Panel } \\
\text { discussion }\end{array}$ & 6.25 & 35.42 & 18.75 & 39.58 \\
\hline $\begin{array}{c}\text { Group } \\
\text { activities }\end{array}$ & 20.83 & 43.75 & 10.42 & 27.09 \\
\hline
\end{tabular}




\begin{tabular}{|c|c|c|c|c|}
\hline $\begin{array}{c}\text { Sharing best } \\
\text { practices }\end{array}$ & 8.33 & 29.17 & 8.33 & 49.17 \\
\hline Mentoring & 4.17 & 45.83 & 16.67 & 33.58 \\
\hline Field visits & 6.25 & 45.83 & 12.5 & 35.42 \\
\hline
\end{tabular}

which were mainly related to hands-on experiences. It is essential to pay attention to the number of teachers who expressed that they have not participated in SBTD activities. Therefore, it can be concluded that teachers' participation in SBTD activities in a limited context is satisfactory. Further, it

According to Table 2, three activities can be easily identified: seminars, workshops, and hands-on training in one cluster with above $80 \%$ participation. The second includes group discussions, mentoring, field visits, guest lectures, and get-togethers, with $60 \%$ to $75 \%$. And the third or the lowest type with $46 \%$ including only sharing best practices. Regarding sharing best practices, many participants (49.17\%) were not involved with the activity. While activities such as Guest Lecture (37.5\%), Get together (39.58\%), Mentoring (33.58\%), field visits (35.42\%) and Group activities (25\%) are also showing significant no of non-participants with the activities. It is indicated that some activities are popular among teachers and some other activities are not. If we are to change the system, schools have to attempt activities on hands-on training other than seminars and workshops. At this point, the researcher finds it must be a fact that should be taken into account by the higher authorities to find why all these activities mentioned above are said to be "rarely participated" by the sample in general. Why not these activities have not much frequently happened, what factors negatively influence participation, if any, and how the situation can be remedied must be investigated.

\section{CONCLUSION AND RECOMANDATIONS}

Teacher professional learning is of increasing interest as one way to support the increasingly complex skills students need to learn in preparation for further education and work in the 21 st century. Sophisticated forms of teaching are needed to develop student competencies such as deep mastery of challenging content, critical thinking, complex problemsolving, effective communication and collaboration, and selfdirection. In turn, effective professional development is needed to help teachers learn and refine the pedagogies required to teach these skills. The study's findings related to the level of awareness of SBTD indicated that the Majority of teachers already knew about the SBTD programme and its various activities at their schools. The SBTD programme as a national endeavour has been developed through the years. Therefore, almost everybody in the school system was aware of the programme. The awareness is flourishing to its maximum possible level. The participation in activities done by the name of School-Based Teacher Development is also efficacious. Therefore, it can be concluded that the awareness of the school-based teacher development programme as a national level policy initiative that has been instructed under the Programme of School Improvement (PSI) is satisfactory. The findings indicated that teachers know well what this programme is and what this programme aims to achieve. The findings relating to the participation of teachers in SBTD activities showed that the teacher participation, even though $87.5 \%$ of teachers agree that they are aware of SBTD, a large no of participants did not involve in some of the activities in implementing school-based teacher development programmes and the challenges they face.

\section{REFERENCES}

[1] Arachchi. C. K. (2015) Key elements of school-based teacher development in Sri Lanka: A case study of Colombo district schools, paper presented at the international conference on social entrepreneurship and sustainable development, Tata

[2] Institute of Social Sciences (TISS), Mumbai, India, (Feb.04-07) 2015 .

[3] Bandara, S. (2018 A). School-Based Teacher Development Programs in Secondary Schools in Sri Lanka. International Journal of Research- GRANTHAALAYAH, 6(5), 190-200.

[4] Bandara, S. (2018 B). "The Influences of Administration System and Policies to Development of School-Based Teacher

[5] Development Programs in Sri Lanka", International Journal of Science and Research (IJSR), 7 (5), May 2018, 1128 - 1134.

[6] Fullan, M. (1995). Professional Development in Education: New Paradigms and Practices. (Guskey, T. \& Huberman, M. Eds.) New York: Teachers College Press.

[7] Kugamoorthy, S. (2017). School-Based Teacher Development: Opportunities and Challenges for Teachers in Jaffna District. Open University Research sessions-2017. P 61-66.

[8] Linda, D. (2005). Preparing Our Teachers for Teaching as a profession. Education Digest. 71, p 22-27.

[9] Nawastheen, F.M., Wanasinghe, W.M.S. and Seneviratne, P., (2017). A Study on PGDE Student-Teacher Efficacy Beliefs in the Sri Lankan Context. OUSL Journal, 12(1), pp.27-44. DOI: http://doi.org/10.4038/ouslj.v12i1.7360

[10] Silva, K.T., Sethunga, P., Jayasuriya, J., and Sugathapala, R.D. (2007). The Study on School-Based Teacher Development Programmes.Retrievedfrom http://arts.pdn.ac.lk/education/images/SBTD\%20FINAL\%20REP ORT.pdf

[11] Yoon, K. S., Duncan, T., Lee, S. W. Y., Scarloss, B., and Shapley, K. (2007). Reviewing the evidence on how teacher professional development affects student achievement. Issues and Answers Report, REL2007-No.033. Washington, DC: US Department of Education, Institute of Education Sciences, National Center for Education Evaluation and Regional Assistance, Regional Educational Laboratory Southwest. 